\title{
Multilocus Sequence Analysis Reveals Genetic Diversity in Xanthomonads Associated With Poinsettia Production
}

W. Rockey, N. Potnis, and S. Timilsina, Department of Plant Pathology, University of Florida, Gainesville 32611; J. C. Hong, U.S. Horticultural Research Laboratory, United States Department of Agriculture-Agricultural Research Service, Fort Pierce, FL 34945; G. E. Vallad, University of Florida, Gulf Coast Research and Education Center, Wimauma 33598; J. B. Jones, Department of Plant Pathology, University of Florida, Gainesville; and D. J. Norman, University of Florida, Mid-Florida Research and Education Center, Apopka 32703

\begin{abstract}
Rockey, W., Potnis, N., Hong, J. C., Timilsina, S., Vallad, G. E., Jones, J. B., and Norman, D. J. 2015. Multilocus sequence analysis reveals genetic diversity in xanthomonads associated with poinsettia production. Plant Dis. 99:874-882.

Xanthomonas axonopodis pv. poinsettiicola is traditionally identified as the primary causal agent of bacterial leaf spot on poinsettia (family Euphorbiaceae). Sixty-seven strains of xanthomonads isolated from lesions associated with several species within the family Euphorbiaceae were collected over a 64-year period. The pathogenicity of these strains was compared on several potential hosts and they were analyzed by multilocus sequence analysis (MLSA) using six housekeeping genes. The 67 Xanthomonas strains associated with poinsettia production were separated into three distinct clades based on MLSA. The first clade identified contained the $X$. axonopodis pv. poinsettiicola reference strain $\left(\mathrm{LMG} 849^{\mathrm{PT}}\right)$. A second clade was more closely related to X. hortorum pv. pelargonii (LMG7314 ${ }^{\mathrm{PT}}$ ) and the third clade contained the $X$. codiaei type strain $\left(\mathrm{LMG} 8678^{\mathrm{T}}\right)$. This analysis indicated that there may also be other closely related pathovars or species of Xanthomonas

that can infect poinsettia. Strains from the three clades could not be distinguished by symptoms or virulence on poinsettia plants. Strains capable of infecting geranium were found in all three clades, although the extent of leaf spot formation and number of systemic infections were significantly less than those produced by $X$. hortorum pv. pelargonii strains, typically the main causal agent of bacterial leaf spot on geranium. Clade III also contained strains isolated from zebra plant (Aphelandra squarrosa, family Acanthaceae), which is a newly recognized host for X. codiaei and X. axonopodis pv. poinsettiicola. Xanthomonas leaf spot is a serious threat to poinsettia production that can be caused by several Xanthomonas spp. that can infect different ornamental plant hosts. It is imperative that growers maintain a strict sanitation program because reservoirs of inoculum can occur on a number of ornamental hosts.
\end{abstract}

Poinsettia (Euphorbia pulchrimma) is the number one flowering potted plant sold in the United States, with an annual wholesale value of over \$200 million (United States Department of Agriculture). Poinsettia cultivars have been produced and developed in the United States since the 1920s (Benson et al. 2002). Bacterial leaf spot of poinsettia, incited by Xanthomonas axonopodis pv. poinsettiicola, was identified in U.S. poinsettia production in 1960 (McFadden and Mowry 1962). X. axonopodis pv. poinsettiicola has since been described in every country where poinsettias have been cultivated.

Xanthomonads have also been associated with other members of family Euphorbiaceae. Crown-of-thorns (Euphorbia milii) (McFadden and Mowry 1962; Miller and Seymour 1972) and croton (Codiaeum variegatum) (Chase 1985) were described as hosts for $X$. axonopodis pv. poinsettiicola. Both plant genera, like poinsettia, are popular ornamental crops. Xanthomonas strains isolated from croton were considered to be part of the pathovar poinsettiicola based on biochemical tests and on their ability to cause similar symptoms on either poinsettia or croton (Chase 1985). Vauterin et al. (2000) later reclassified the strains from croton as $X$. codiae $i$, based on further biochemical tests, metabolic profiles, and DNA-DNA homology.

Leaf spots on geranium (Pelargonium hortorum, family Geraniaceae) caused by xanthomonads are usually considered

Corresponding author: D. J. Norman; E-mail: djn@ufl.edu

*The $\boldsymbol{e}$-Xtra logo stands for "electronic extra" and indicates that two supplementary figures are published online.

Accepted for publication 29 December 2014.

http://dx.doi.org/10.1094/PDIS-08-14-0867-RE

(C) 2015 The American Phytopathological Society to be caused by $X$. hortorum pv. pelargonii; however, we have isolated $X$. axonopodis pv. poinsettiicola from geranium based on fatty acid methyl ester (FAME) analysis using the MIDI software (Sherlock ver. 4.5). Growers frequently report that symptoms of Xanthomonas sp.-caused diseases on geranium vary greatly from a few leaf spots to blights and wilts. They also report that the purchase of indexed Xanthomonas sp.-free plants does not preclude outbreaks of Xanthomonas leaf spot. Other ornamental crops within a given production facility are suspected to be reservoirs of pathogenic xanthomonads.

Within a phytobacterial species, host of origin is usually used as the primary factor in presumptive pathovar identification. Thus, there is a potential for misidentification and inaccurate inclusion of a strain within a pathovar. Phenotypic identification methods are frequently criticized for being less precise than genomic analysis. Phenotypic identification systems can be more precise if they are combined with genomic data to describe representative strains. Commonly used genomic methods such as repetitive extragenic palindromic sequence (Rep) PCR (Louws et al. 1994; Rademaker et al. 2000, 2005), amplified fragment length polymorphism (AFLP) (Bui Thi Ngoc et al. 2010; Janssen et al. 1996; Radermaker et al. 2000; Vos et al. 1995), and restriction fragment length polymorphism (RFLP) (Simões et al. 2007) were standard for Xanthomonas sp. determination until the late 1990s (Bui Thi Ngoc et al. 2010; Simões et al. 2007). DNA-DNA hybridization became the standard to identify species of Xanthomonas in the mid1990s (Johnson 1994; Martens et al. 2008); however, DNA-DNA hybridization requires skilled technicians and standardization of techniques (Brenner 1973; Hildebrand et al. 1990; Johnson 1994; Marmur and Doty 1962).

In this study, we used multilocus sequence analysis (MLSA) (Almeida et al. 2010; Bui Thi Ngoc et al. 2010; Marcelletti et al. 2010; Martens et al. 2008; Young et al. 2008) to characterize the Xanthomonas strains associated with leaf spots on commercial poinsettias, other related euphorbias, and geranium. In MLSA, housekeeping genes 
conserved within a genus are sequenced and analyzed to determine phylogenetic relationships. When using MLSA to compare species within a genus, it is suggested to use at least five highly conserved genes that are universally distributed and are present in single copies at distinct locations within their respective chromosomes (Almeida et al. 2010; Martens et al. 2008). MLSA is considered to be superior to Rep-PCR, AFLP, and RFLP for species identification (Martens et al. 2008). For this study, we chose six housekeeping genes to examine Xanthomonas strains associated with poinsettia production.

\section{Material and Methods}

Bacterial strains. Sixty-seven Xanthomonas sp. isolated from poinsettia, crown of thorns, croton, zebra plant, geranium, nandina, and a number of type strains were utilized in this study (Table 1). These strains were isolated over a 64-year period, mainly from the Euphorbiaceae family. Xanthomonas strains isolated in 2010 from zebra plant (Aphelandra squarrosa in the family Acanthaceae) were also included in this study. Strains isolated from zebra plant were identified as $X$. axonopodis pv. poinsettiicola by FAME analysis, with similarity coefficients $>0.8$. All strains were stored in $15 \%$ glycerol at $-80^{\circ} \mathrm{C}$ and revived when needed.

Genomic DNA extraction, PCR protocols, and sequencing. Bacterial strains were revived from $-80^{\circ} \mathrm{C}$ storage by streaking onto nutrient agar (NA; Becton, Dickinson, Sparks, MA) plates and incubating at $28^{\circ} \mathrm{C}$. Single colonies were then restreaked twice to limit possible contamination. After $24 \mathrm{~h}$ of growth, genomic DNA was extracted using an illustra bacteria genomicPrep Mini Spin kit (GE, Pittsburgh, PA). Purified DNA was stored in elution buffer at $-20^{\circ} \mathrm{C}$.

Six gene loci (fusA, gapA, gltA, gyrB, lacF, and lepA) were sequenced using primers described by Almeida et al. (2010). Each amplification reaction contained $25 \mu \mathrm{l}$ of GoTaq Green Master Mix (Promega Corp., Madison, WI) with $5.0 \mu$ l of both upstream and downstream primers, and $2 \mathrm{ng}$ of DNA. Total volume was adjusted to $50 \mu \mathrm{l}$ using sterile deionized water. Amplification of the DNA sequences was conducted in a thermocycler with the following thermal profile (Bio-Rad, Hercules, CA): a hot start of $95^{\circ} \mathrm{C}$ for $5 \mathrm{~min}$; followed by 30 cycles of $95^{\circ} \mathrm{C}$ for $15 \mathrm{~s}, 54^{\circ} \mathrm{C}$ for $30 \mathrm{~s}$, and $72^{\circ} \mathrm{C}$ for $60 \mathrm{~s}$; and a 10 -min extension at $72^{\circ} \mathrm{C}$ in the last cycle (Hong et al. 2012). The annealing temperature was adjusted according to the primers used. The PCR products were separated on a $1.0 \%$ agarose gel and visualized with UV light via SYBR Green Gel stain. Individual products were sequenced using a Sanger sequencer (Interdisciplinary Center for Biotechnology Research, ICBR, University of Florida, Gainesville).

MLSA analysis. To determine the phylogenetic relationships of the strains, the sequences of each of the six genes were analyzed separately as well as combined. Initially, raw sequence data were assigned Phred quality scores, trimmed, and assembled using CodonCode Aligner (ver. 4.0.3; CodonCode Corp., Centerville, MA). Sequences were aligned using CLUSTALW implemented in MEGA 5.05 (Tamura et al. 2011; Thompson et al. 1994). Maximum-likelihood searches were conducted using MEGA5 according to the general time-reversible model with $\gamma$-distributed invariant sites parameter suggested for the data matrix by Modeltest (Posada and Crandall 1998). Using the same data matrix that was analyzed by MEGA and the model suggested by MODELTEST, Bayesian Markov chain Monte Carlo phylogenetic analysis was conducted with MrBayes 3 (Huelsenbeck et al. 2001; Ronquest and Huelsenbeck 2003). Each Markov chain in the Bayesian search was started from a random tree and run for 106 cycles, sampling every 100th cycle from the chain, with each tree being rooted with Stenotrophomonas maltophilia as an outlier. Four chains were run simultaneously (three hot and one cold). Each simulation was run twice and the default settings for the priors on the rate matrix ( 0 to 100), branch lengths ( 0 to 10 ), and proportion of invariant sites ( 0 to 1 ) were used. Stationarity of the sum of the natural log of the likelihood values of the trees in each of the four chains, weighted according to the temperatures of the chains, was evaluated by monitoring likelihood values graphically. The initial 100 trees in each run were discarded as burn-in. The remaining trees were used to construct majority-rule consensus trees. Bayesian posterior probabilities for each clade were derived from trees remaining after discarding the burn-in samples. For ease of visual comparison with bootstrap values, we present these probabilities as percentage whole numbers (0 to 100). Six additional strains and their sequences were added to the analysis as references (Almeida et al. 2010).

Host range test. A limited host range experiment was conducted using the 67 strains listed in Table 1. Inoculations were replicated three times for each of the following plants: poinsettia ('Eckespoint Prestige Red'), crown-of-thorns ('Red Splendens'), zonal geranium ('Patriot Bright Red'), zebra plant ('Dania'), and two croton cultivars ('Gold Dust' and 'Gold Star'). Three plants of each variety were arranged in a single block. Bacterial strains were incubated on NA plates at $28^{\circ} \mathrm{C}$ for $48 \mathrm{~h}$. A suspension of each strain was spectrophotometrically adjusted (A600) in saline ( $\mathrm{NaCl}$ at $8.5 \mathrm{~g} /$ liter) to $1 \times 10^{8} \mathrm{CFU} / \mathrm{ml}$. Approximately $150 \mathrm{ml}$ of this bacterial suspension was sprayed onto the entire group of plants. Immediately after inoculation, plants were bagged for $24 \mathrm{~h}$ to maintain a humid environment. After $24 \mathrm{~h}$, the bags were removed and the plants were visually observed for symptoms daily for 30 days. The host range test was repeated as described above.

Leaf spots were enumerated, with plants exhibiting greater than 100 leaf spots recorded as $>100$. Average leaf spot counts were tabulated from poinsettia, crown-of-thorns, geranium, and croton (Table 2). Frequently, large necrotic zones developed on the zebra plants (Supplementary Fig. S1) with no distinct leaf spots; thus, an alternate rating scale was utilized as follows: $0=$ no symptoms, $1=1$ to 5 leaf spots 5 to $20 \mathrm{~mm}$ in size, and $2=$ large necrotic zones developed on leaves followed by defoliation. Severity of plant symptoms for each species was statistically compared between strains in the three distinct MLSA clades using analysis of variance (ANOVA) and least significant difference (LSD) procedures (SigmaPlot 12.5).

MLSA clustering revealed three distinct clades of xanthomonads infecting poinsettia plants. In order to gain a better understanding of how these populations affected geranium production, additional virulence tests were conducted. In the first test, we selected six representative strains: $X$. axonopodis pv. poinsetticola (LMG849 ${ }^{\mathrm{PT}}$, isolated from poinsettia, clade I), unknown Xanthomonas sp. (X808, isolated from poinsettia, clade II), X. codiaei $\left(\mathrm{LMG} 8678^{\mathrm{T}}\right.$, isolated from croton, clade III), unknown Xanthomonas sp. (X1730, isolated from geranium, clade III), X. hortorum pv. pelargonii $\left(\mathrm{LMG} 7314^{\mathrm{PT}}\right.$, isolated from geranium), and $X$. campestris pv. campestris (LMG568 ${ }^{\mathrm{PT}}$, isolated from Brassica oleracea). In this test, approximately $14 \mathrm{~cm}$ of high zonal geranium (Patriot Bright Red) was spray inoculated as previously described but, after inoculation, plants were incubated in an environmental growth chamber (Big Foot AC-60; BioChambers, Winnipeg, MB, Canada) maintained at $30^{\circ} \mathrm{C}$ and $50 \%$ relative humidity, with a 12 -h light cycle $\left(310 \mu \mathrm{mol} \mathrm{mm} \mathrm{m}^{-2} \cdot \mathrm{s}^{-1}\right)$. After 2 weeks, the number of leaf spots were enumerated on each plant (10 replicates) and representative spots were used to reisolate and confirm infection. After 4 weeks, a cross section of the plant stem at the soil line was surface sterilized, macerated, and streaked onto NA agar to check for systemic infection. This experiment was repeated three times and included a noninoculated control. The numbers of leaf spots were statistically compared between strains using ANOVA and LSD procedures (SigmaPlot 12.5).

In order to mimic wet humid conditions commonly observed in commercial production and see the effect on virulence, a second test was done with $X$. codiaei $\left(\mathrm{LMG} 8678^{\mathrm{T}}\right.$, isolated from croton, clade III). Geranium plants were inoculated as described above, with the exception that plants were incubated in a greenhouse and misted every $10 \mathrm{~min}$ for $3 \mathrm{~s}$ during daylight hours. Leaf spot development was visually monitored for 4 weeks, and plants were sampled and checked for systemic infections as previously described. Testing 
was repeated three times and numbers of leaf spots was statistically compared between strains using ANOVA and LSD procedures (SigmaPlot 12.5)

\section{Results}

MLSA analysis. MLSA analysis of the 67 strains in this study revealed three Xanthomonas populations capable of infecting poinsettia (Fig. 1). Clade I contained the largest percentage of strains, including the pathotype strain for $X$. axonopodis $\mathrm{pv}$. poinsetticola (LMG849 ${ }^{\mathrm{PT}}$ ). Strains within this clade were recovered from poinsettia, crown-of-thorns, and nandina (Nandina domestica, family Berberidaceae). In Florida, Nandina is frequently infected with a nondescribed Xanthomonas sp. FAME analysis identified strain X1676 as X. axonopodis pv. poinsetticola. MLSA placed strain X1676 on the margin of clade I (Fig. 1), which suggests that it may be a separate pathovar. Further support for this premise is that X1676 produced no symptoms on plants tested in this study.

Clade II contained eight strains closely related by MLSA to $X$. hortorum pv. pelargonii. Seven of the eight strains were isolated from poinsettia. Four X. hortorum pv. pelargonii strains, including the pathotype strain $\left(\mathrm{LMG} 7314^{\mathrm{PT}}\right.$ ), were located in a separate clade above clade II.
Clade III contained strains originally isolated from poinsettia, croton, geranium, zebra plant, and aglaonema. Clade III contained the $X$. codiaei pathotype strain (LMG8678 ${ }^{\mathrm{T}}$ ) described by Vauterin et al. (2000). X. codiaei has never been described as a pathogen of geranium or aglaonema. Two strains isolated from geranium (X1721 and X1730) grouped into clade III and were isolated from a greenhouse production facility that also cultivated poinsettia. Strain $\mathrm{X} 1720$ was also isolated at the same time from the same facility as X1721 but from an infected poinsettia plant. All Xanthomonas strains isolated in Florida in 2010 from zebra plants grouped into clade III.

An additional subclade containing two Xanthomonas strains (X870 and X874), both isolated in Florida in 1989, was separated from clade III. At the time of collection, these strains were presumptively identified as $X$. axonopodis pv. poinsettiicola based on their host of origin (Euphorbia sp.). These strains were clearly separated in this MLSA study from other clades; however, no other information exists regarding host species or pathovar designation. Both strains produced symptoms on poinsettia like $X$. codiaei and $X$. axonopodis pv. poinsettiicola strains.

Host range test. Poinsettias were the most susceptible of all the plants, with disease symptoms developing with most strains tested in this study (Table 2; Fig. 2). Symptoms varied from a few spots to $>100$ spots per plant. Leaves with greater than 75 spots quickly

Table 1. Xanthomonas strains utilized in this study including original host, date of isolation, and source

\begin{tabular}{|c|c|c|c|c|}
\hline Lab ID & Original ID & Original host (species) & Date of isolation ${ }^{a}$ & Source $^{b}$ \\
\hline $\mathrm{X} 54$ & DPI-083-6248 & Poinsettia (Euphorbia pulcherrima) & 1983 & JWM \\
\hline X87 & PDD-225-84 & Croton (Codiaeum variegatum) & 1984 & DDB \\
\hline X202 & GWS 2705B-85 & Poinsettia (E. pulcherrima) & 1985 & GWS \\
\hline X340 & DPI-P87-4567 & Poinsettia (E. pulcherrima) & 1987 & JWM \\
\hline X349 & $066-2894$ & Poinsettia (E. pulcherrima) & 1966 & RS \\
\hline $\mathrm{X} 350$ & $070-4220$ & Crown-of-thorns (Euphorbia milli) & 1970 & RS \\
\hline X351 & C. po 2 & Poinsettia (E. pulcherrima) & $<1987$ & JBJ \\
\hline $\mathrm{X} 352$ & $071-425$ & Crown-of-thorns (E. milli) & 1971 & $\mathrm{RS}$ \\
\hline $\mathrm{X} 353$ & $066-2936$ & (Euphorbia sp.) & 1966 & RS \\
\hline X356 & $071-424$ & Crown-of-thorns (E. milli) & 1971 & RS \\
\hline X357 & $071-559$ & Crown-of-thorns (E. milli) & 1971 & RS \\
\hline X358 & 071-604 & Crown-of-thorns (E. milli) & 1971 & RS \\
\hline X386 & NZTCC 3278 & Poinsettia (E. pulcherrima) & 1972 & NZTCC \\
\hline X387 & NZTCC 3279 & Poinsettia (E. pulcherrima) & 1972 & NZTCC \\
\hline X394 & NZTCC 5730 & Euphorbia acalyphoides & 1965 & NZTCC \\
\hline X395 & NZTCC 5779 & Poinsettia (E. pulcherrima) & 1950 & NZTCC \\
\hline X419 & $\ldots$ & Poinsettia (E. pulcherrima) & 1988 & MREC \\
\hline X506 & A2726 & Poinsettia (E. pulcherrima) & $<1988$ & AMA \\
\hline X507 & A2727 & Poinsettia (E. pulcherrima) & $<1988$ & AMA \\
\hline X516 & A2737 & Poinsettia (E. pulcherrima) & $<1988$ & AMA \\
\hline X517 & A2738 & Poinsettia (E. pulcherrima) & $<1988$ & AMA \\
\hline X525 & A2746 & Poinsettia (E. pulcherrima) & $<1988$ & AMA \\
\hline X541 & A 2762 & Poinsettia (E. pulcherrima) & $<1988$ & AMA \\
\hline X616 & DPI-071-604 & Crown-of-thorns (E. milli) & 1971 & JWM \\
\hline X644 & DPI-066-2936 & Poinsettia (E. pulcherrima) & 1966 & JWM \\
\hline X661 & PDD-1772-88 & 'Maria' (Aglaonema commutatum) & 1988 & DDB \\
\hline
\end{tabular}

(continued on next page)

\footnotetext{
a Symbol "<" indicates date strain acquired, isolation date unknown. Florida, Gainesville, FL 32611.

c Pathotype strain Xanthomonas campestris pv. campestris.

${ }^{\mathrm{d}}$ Pathotype strain for $X$. axonopodis pv. poinsettiicola.

e Pathotype strain for $X$. axonopodis pv. begonia.

f Pathotype strain for $X$. hortorum pv. pelargonii.

g Type strain $X$. codiaei.
}

b Strains were obtained from the following laboratories: AMA = Anne M. Alvarez, Department of Plant Pathology, University of Hawaii at Manoa, Honolulu, HI, 96822; ATCC = American Type Culture Collection, Manassas, VA 20108; BCCM/LMG = Belgian Coordinated Collections of Micro-organisms, Brussel, Belgium; DAC =; DCH = Donald C. Hildebrand, Department of Plant Pathology, University of California, Berkeley, CA 94704; DDB = D. D. Brunk, Plant Disease Diagnostics, Inc., Apopka, FL 32703; DLT = Darryl L. Thomas, Syngenta Flowers PO Box 1349. Gilroy CA 95021; GWS = Gary W. Simone, Department of Plant Pathology, University of Florida, Gainesville, FL 32611; JWM = J. W. Miller, Division of Plant Industry, Florida Department of Agriculture and Consumer Services, Gainesville, FL 32602; JBJ = Jeffrey B. Jones, Department of Plant Pathology, University of Florida, Gainesville, FL 32611; MREC = Mid-Florida Research and Education Center, University of Florida, Apopka, FL 32703; NZTCC = New Zealand Type Culture Collection; SK = Sven Keil, IDENTXX GmbH, Maybachstrasse 50, 70469 Stuttgart, Germany; and RS = Robert Stall, Department of Plant Pathology, University of 
turned chlorotic and abscised. X661 isolated from aglaonema (family Araceae) was highly virulent on poinsettia but produced little to no symptoms on other host plants (Table 2; Fig. 2). Interestingly, even the $X$. campestris pv. campestris (LMG568 ${ }^{\mathrm{PT}}$ ) type strain produced leaf spots on poinsettia $(\bar{x}=30)$. There were no significant differences in number of leaf spots produced on poinsettia between the three MLSA clades.

Two cultivars of croton were utilized in this study (Gold Dust and Gold Star) and only three strains-X1903, X1904, and the $X$. codiaei type strain (LMG8678)-produced symptoms on these croton cultivars. These three strains had identical sequences for the six genes used in this study. Gold Dust and Gold Star were reported as being very susceptible to $X$. axonopodis pv. poinsettiicola in the 1980s (Chase 1985). We also have no information on the croton cultivar from which strains were isolated. However, symptoms in this study were limited, with an average of $<11$ leaf spots per plant. Other strains in clade III isolated from croton did not produce symptoms on croton. Only strains from clades I and II produced leaf spots on crown-of-thorns, with no symptoms being observed with strains from clade III. Strains from all clades produced symptoms on zebra plants. However, disease caused by strains from clade III was significantly $(P=$ $0.05)$ more severe than for strains from other clades. Clade III also contained all strains originally isolated from zebra plant.
Many of these strains were highly virulent on zebra plant, forming large, coalescing, necrotic leaf spots that eventually resulted in leaf abscission.

Geraniums were not previously considered to be a host of $X$. axonopodis pv. poinsettiicola. However, strains within clades I, II, and III produced leaf spot on zonal geranium. The highest number of leaf spots was observed with strains in clade III. However, there were no significant differences between the number of spots observed on geranium between clades I and III. The two strains in clade III ( $X$. codiaei type strains LMG8678 ${ }^{\mathrm{T}}$ and $\mathrm{X} 1730$ ) produced a limited number of leaf spots when geranium plants were maintained at $30^{\circ} \mathrm{C}$ (Table 3 ). Leaf spots produced by these strains were difficult to count at times because they developed primarily on the leaf margins and frequently merged. The average number of leaf spots per plant for these two strains from cluster III was significantly lower $(P=0.05)$ when compared with the high numbers $(\bar{x}=230)$ produced by the $X$. hortorum pv. pelargonii (LMG7314 ${ }^{\mathrm{PT}}$ ) pathovar reference strain. All the geranium plants $(30 / 30)$ sprayed with the reference strain LMG $7314^{\mathrm{PT}}$ became systemically infected whereas only $13 \%$ $(4 / 30)$ and $10 \%(3 / 30)$ of the plants were systemically infected when inoculated with strains $\mathrm{LMG} 8678^{\mathrm{T}}$ and $\mathrm{X} 1730$, respectively. Plants inoculated with LMG8678 ${ }^{\mathrm{T}}(X$. codiaei type strains) and incubated under mist developed foliar blight with

Table 1. (continued from previous page)

\begin{tabular}{|c|c|c|c|c|}
\hline Lab ID & Original ID & Original host (species) & Date of isolation ${ }^{a}$ & Source ${ }^{b}$ \\
\hline X699 & DPI-P88-4093-4 & Poinsettia (E. pulcherrima) & 1988 & JWM \\
\hline X700 & DPI-P88-4093-2 & Poinsettia (E. pulcherrima) & 1988 & JWM \\
\hline X701 & DPI-P85-2020 & Poinsettia (E. pulcherrima) & 1985 & JWM \\
\hline X749 & PDD-539-89 & Poinsettia (E. pulcherrima) & 1989 & DDB \\
\hline X773 & DPI-88-5463-4 & Croton (C. variegatum) & 1988 & JWM \\
\hline X808 & GWS-2365B2-88 & Poinsettia (E. pulcherrima) & 1988 & GWS \\
\hline X822 & DPI-89-3258-1 & Crown-of-thorns (E. milli) & 1989 & JWM \\
\hline X835 & PDD-3199-89 & (Euphorbia sp.) & 1989 & DDB \\
\hline X842 & $\ldots$ & Crown-of-thorns (E. milli) & 1989 & MREC \\
\hline X852 & PDD-3349-89 & Poinsettia (E. pulcherrima) & 1989 & DDB \\
\hline $\mathrm{X} 870$ & DPI-P89-4476-3 & Euphorbia sp. & 1989 & JWM \\
\hline X874 & DPI-P89-4476-2 & Euphorbia sp. & 1989 & JWM \\
\hline X879 & DPI-P89-5239-2 & Poinsettia (E. pulcherrima) & 1989 & JWM \\
\hline X979 & LMG568 ${ }^{\mathrm{PTc}}$ & Cabbage (Brassica oleracea) & 1957 & ATCC \\
\hline X1144 & XP137-A & (Euphorbia sp.) & $<1990$ & $\mathrm{DCH}$ \\
\hline X1302 & $\ldots$ & Croton (C. variegatum) & 1991 & MREC \\
\hline $\mathrm{X} 1505$ & $\ldots$ & Croton (C. variegatum) & 1993 & MREC \\
\hline X1634 & $\ldots$ & Poinsettia (E. pulcherrima) & 1997 & MREC \\
\hline $\mathrm{X} 1676$ & $\ldots$ & Nandina (Nandina domestica) & 1998 & MREC \\
\hline $\mathrm{X} 1720$ & $\ldots$ & Poinsettia (E. pulcherrima) & 2000 & MREC \\
\hline $\mathrm{X} 1721$ & $\ldots$ & Geranium (Pelargonium sp.) & 2000 & MREC \\
\hline $\mathrm{X} 1730$ & $\ldots$ & Geranium (Pelargonium sp.) & 2001 & MREC \\
\hline $\mathrm{X} 1763$ & $\ldots$ & Poinsettia (E. pulcherrima) & 2002 & MREC \\
\hline $\mathrm{X} 1807$ & $\ldots$ & Crown-of-thorns (E. milli) & 2004 & MREC \\
\hline $\mathrm{X} 1848$ & $\ldots$ & Poinsettia (E. pulcherrima) & 2010 & MREC \\
\hline $\mathrm{X} 1877$ & LMG849PTd & Poinsettia (E. pulcherrima) & 1964 & $\mathrm{BCCM} / \mathrm{LMG}$ \\
\hline $\mathrm{X} 1878$ & LMG7228 & Geranium (Pelargonium sp.) & 1986 & $\mathrm{BCCM} / \mathrm{LMG}$ \\
\hline X1879 & LMG7303 $3^{\mathrm{PTe}}$ & Begonia (Begonia sp.) & 1986 & $\mathrm{BCCM} / \mathrm{LMG}$ \\
\hline $\mathrm{X} 1880$ & LMG7314 ${ }^{\text {PTf }}$ & Geranium (Pelargonium sp.) & 1986 & $\mathrm{BCCM} / \mathrm{LMG}$ \\
\hline $\mathrm{X} 1881$ & MEX 1 & Geranium (Pelargonium sp.) & 2011 & DLT \\
\hline $\mathrm{X} 1890$ & MEX 11 & Geranium (Pelargonium sp.) & 2011 & DLT \\
\hline X1891 & 613 & Poinsettia (E. pulcherrima) & 2009 & SK \\
\hline $\mathrm{X} 1892$ & 614 & Poinsettia (E. pulcherrima) & 2009 & SK \\
\hline X1893 & 616 & Poinsettia (E. pulcherrima) & 2010 & SK \\
\hline X1894 & 617 & Begonia (Begonia sp.) & $<2011$ & SK \\
\hline $\mathrm{X} 1898$ & 612 & Poinsettia (E. pulcherrima) & 2007 & SK \\
\hline X1899 & 615 & Poinsettia (E. pulcherrima) & 2009 & SK \\
\hline X1901 & $\ldots$ & Zebra plant (Aphelandra squarrosa) & 2011 & MREC \\
\hline X1903 & $\ldots$ & Zebra plant (A. squarrosa) & 2011 & MREC \\
\hline X1904 & $\ldots$ & Zebra plant (A. squarrosa) & 2011 & MREC \\
\hline X1906 & LMG8678 ${ }^{\mathrm{Tg}}$ & Croton $(C$. variegatum) & 1987 & $\mathrm{BCCM} / \mathrm{LMG}$ \\
\hline
\end{tabular}


extensive merged leaf spots (Supplementary Fig. S2). The number of systemically infected plants also increased to $23 \%$ $(7 / 30)$.

\section{Discussion}

Ornamental plants are propagated and grown in close proximity, frequently under overhead irrigation. Within greenhouse structures, both high temperatures and humidity are common during production. In addition, to maintain profitability, many greenhouse facilities employ an intense multicrop production system, with many different genera of plants produced in close proximity. These environmental conditions are conducive to the development of many types of bacterial infections. When these infections occur, a presumptive disease diagnosis and pathogen identification is done based on symptoms observed on associated hosts. Further complicating this process is the fact that the many Xanthomonas spp. and pathovars have poorly defined host ranges. Thus, pathogens may be misidentified based on symptoms. This is further complicated when incorrectly identified strains are then used to develop phenotypic or diagnostic tests.
Whole bacterial genome sequencing will eventually help correctly identify and classify Xanthomonas spp. and pathovars, and aid in the development of new identification methods. However, until the cost of whole-genome sequencing is reduced, MLSA is an effective alternative (Almeida et al. 2010; Bui Thi Ngoc et al. 2010; Marcelletti et al. 2010; Martens et al. 2008; Young et al. 2008). In our study, we observed three distinct xanthomonad populations that can infect poinsettia, representing at least two described species ( $X$. axonopodis pv. poinsetticola and $X$. codiaei). One cannot distinguish these pathogen groups based on symptoms or disease severity. There are other potential Xanthomonas spp. that have the potential to infect and cause similar symptoms on poinsettia. This was demonstrated by the $X$. campestris pv. campestris type stain causing symptoms on poinsettia. Clades reported in this study are similar to those observed by Young et al. (2008). Young's MLSA study used four genes that clearly separated $X$. codiaei from $X$. campestris pv. campestris, $X$. hortorum pv. pelargonii, and $X$. axonopodis pv. begoniae. However, Young did not include $X$. axonopodis pv. poinsetticola strains in his study. Further work should be done to compare phylogenetic relationship and host susceptibility of

Table 2. Multilocus sequence analysis (MLSA) clade designation and pathogenicity of 67 Xanthomonas strains on four hosts, and date of strain isolation

\begin{tabular}{|c|c|c|c|c|c|c|}
\hline $\begin{array}{l}\text { MLSA } \\
\text { clade }\end{array}$ & Lab ID & $\begin{array}{l}\text { Poinsettia (Euphorbia } \\
\text { pulcherrima) leaf spot } \\
\text { count }^{\mathrm{a}}\end{array}$ & $\begin{array}{l}\text { Geranium (Pelargonium } \\
\text { sp.) leaf spot count }{ }^{\mathbf{a}}\end{array}$ & $\begin{array}{l}\text { Crown-of-thorns } \\
\text { (Euphorbia milli) } \\
\text { leaf spot count }\end{array}$ & $\begin{array}{l}\text { Zebra plant (Aphelandra } \\
\text { squarrosa) severity } 0 \text { to } 2^{\mathrm{b}}\end{array}$ & $\begin{array}{c}\text { Date of } \\
\text { isolation }\end{array}$ \\
\hline I & X54 & 57 & 3 & 0 & 0.83 & 1983 \\
\hline I & X340 & 74 & 3 & 0 & 0.5 & 1987 \\
\hline I & X349 & 42 & 3 & 0 & 0 & 1966 \\
\hline I & X350 & 70 & 5 & 5 & 0 & 1970 \\
\hline I & X352 & 62 & 0 & 0 & 0.6 & 1971 \\
\hline I & X353 & 0 & 0 & 0 & 0.17 & 1966 \\
\hline I & X356 & 71 & 0 & 0 & 0 & 1971 \\
\hline I & X357 & 96 & 3 & 5 & 0 & 1971 \\
\hline I & X358 & 76 & 0 & 0 & 0 & 1971 \\
\hline I & X394 & 100 & 0 & 0 & 0 & 1965 \\
\hline I & X395 & 100 & 0 & 0 & 0.3 & 1950 \\
\hline I & X507 & 80 & 0 & 0 & 0 & $<1988$ \\
\hline I & X516 & 88 & 0 & 0 & 0.67 & $<1988$ \\
\hline I & X517 & 100 & 0 & 0 & 0.17 & $<1988$ \\
\hline I & X525 & 100 & 0 & 0 & 0.3 & $<1988$ \\
\hline I & X541 & 100 & 0 & 0 & 0 & $<1988$ \\
\hline I & X616 & 28 & 0 & 0 & 0.3 & 1971 \\
\hline I & X644 & 62 & 1 & 0 & 0 & 1966 \\
\hline I & X822 & 100 & 0 & 9 & 0 & 1989 \\
\hline I & X835 & 90 & 0 & 0 & 0 & 1989 \\
\hline I & X842 & 58 & 3 & 13 & 0.5 & 1989 \\
\hline I & X1144 & 100 & 2 & 0 & 0 & $<1990$ \\
\hline I & X1676 & 0 & 0 & 0 & 0 & 1998 \\
\hline I & X1807 & 25 & 0 & 0 & 0.17 & 2004 \\
\hline I & LMG849PTd & 100 & 0 & 0 & 0.17 & 1964 \\
\hline I & X1891 & 100 & 0 & 9 & 0.5 & 2009 \\
\hline I & X1892 & 100 & 0 & 0 & 0.17 & 2009 \\
\hline I & X1893 & 100 & 0 & 0 & 0 & 2010 \\
\hline I & X1898 & 100 & 0 & 1 & 0 & 2007 \\
\hline \multirow[t]{2}{*}{ I } & X1899 & 100 & 0 & 0 & 0 & 2009 \\
\hline & & $\bar{x}=76.0$ & $\bar{x}=0.77$ & $\bar{x}=1.4$ & $\bar{x}=0.18$ & \\
\hline II & X351 & 100 & 0 & 10 & 0.3 & $<1987$ \\
\hline II & X386 & 92 & 0 & 0 & 0 & 1972 \\
\hline II & X387 & 92 & 0 & 0 & 0.3 & 1972 \\
\hline
\end{tabular}

\footnotetext{
a Average leaf spots per plant species (greater than 100 leaf spots recorded as $>100$ ). Wilt indicates developed wilt symptoms.

b Rating scale: $0=$ no symptoms, $1=1$ to 5 leaf spots 5 to $20 \mathrm{~mm}$ in size, and $2=$ large necrotic zones developed on leaves followed by defoliation.

c Symbol "<" indicates date strain acquired, isolation date unknown.

d Pathotype strain for Xanthomonas axonopodis pv. poinsettiicola.

e Type stain $X$. codiaei.

f Pathotype strain for $X$. hortorum pv. pelargonii.

g Pathotype strain for $X$. axonopodis pv. begonia.

h Pathotype strain $X$. campestris pv. campestris.
} 
$X$. axonopodis pv. poinsetticola strains with other closely related $X$. axonopodis pathovars, including pvs. citri, fuscans, euvesicatoria, perforans, and alaifae.

Xanthomonas leaf spot remains a serious threat to poinsettia production. The disease can be caused by a number of Xanthomonas spp., including $X$. axonopodis pv. poinsetticola, X. codiaei, $X$. hortorum, and other undescribed xanthomonads. Xanthomonas leaf spot on croton was first described in 1985 (Chase 1985) as $X$. axonopodis pv. poinsetticola. Vauterin and colleagues (1997, $2000)$ reclassified strains from croton as $X$. codiaei. The $X$. codiae $i$ type strain $\left(\mathrm{LMG} 8678^{\mathrm{T}}\right.$ ) in clade III was grouped with other strains isolated from croton, poinsettia, geranium, aglonema, and zebra plant. Interestingly none of the strains in clade III were isolated before 1984 . This suggests that $X$. codiaei was introduced into the United States and became established around this time. In this study, few symptoms were observed on croton even when inoculated with strains isolated from croton. To explain this observation, one must examine the history of croton production in the United States. In the 1980s, production occurred in the United States, with growers usually propagating from their own stock plants. As economic conditions changed, propagation of cuttings shifted to Central American countries, with propagative cuttings being harvested from plants grown in fields. Because there is a zero tolerance for leaf spots on imported ornamental plants, there was extensive pressure to select more resistant plants. Subsequently, the commercially available crotons were more resistant than earlier varieties and Xanthomonas leaf spot became a minor concern in croton production. This is not the case with crops like poinsettia, which are produced in greenhouses where exclusion, not resistance, is the major mechanism of Xanthomonas disease management.

Our data suggest that Xanthomonas infections on geranium are not limited to $X$. hortorum pv. pelargonii but can also be caused by $X$. codiae $i$ and, to a lesser extent, $X$. axonopodis pv. poinsetticola. The virulence of $X$. codiaei strains on geranium is related to environmental conditions, with high humidity, warm temperature, and overhead irrigation directly affecting leaf spot formation and vascular spread.

Greenhouse conditions along with intense multicroping of various ornamental plant species provides a unique environment for the adaptation and expansion of host range. It is possible that Xanthomonas spp. can adapt over time to infect new hosts that would not occur under natural conditions. Thus, one must not assume that species of Xanthomonas have distinct host ranges and do not pose a threat to other crops. Environmental factors, including raised temperature, humidity, and leaf wetness, contribute to the infection of new hosts. Xanthomonad strains isolated from poinsettia and geranium and separated by MLSA in this study provide evidence of more extensive and complex host susceptibility. Ornamental growers should always

Table 2. (continued from previous page)

\begin{tabular}{|c|c|c|c|c|c|c|}
\hline $\begin{array}{l}\text { MLSA } \\
\text { clade }\end{array}$ & Lab ID & $\begin{array}{c}\text { Poinsettia (Euphorbia } \\
\text { pulcherrima) leaf spot } \\
\text { count }^{\mathrm{a}}\end{array}$ & $\begin{array}{l}\text { Geranium (Pelargonium } \\
\text { sp.) leaf spot count }{ }^{\mathbf{a}}\end{array}$ & $\begin{array}{l}\text { Crown-of-thorns } \\
\text { (Euphorbia milli) } \\
\text { leaf spot count }\end{array}$ & $\begin{array}{l}\text { Zebra plant (Aphelandra } \\
\text { squarrosa) severity } 0 \text { to } 2^{\mathrm{b}}\end{array}$ & $\begin{array}{c}\text { Date of } \\
\text { isolation }\end{array}$ \\
\hline II & X701 & 91 & 0 & 0 & 0.3 & 1985 \\
\hline II & X749 & 63 & 0 & 0 & 1 & 1989 \\
\hline II & X808 & 55 & 5 & 0 & 0.17 & 1988 \\
\hline II & X1634 & 32 & 0 & 0 & 0 & 1997 \\
\hline \multirow[t]{2}{*}{ II } & X1848 & 20 & 0 & 0 & 0.17 & 2010 \\
\hline & & $\bar{x}=80$ & $\bar{x}=0.62$ & $\bar{x}=1.3$ & $\bar{x}=0.28$ & $\ldots$ \\
\hline III & X87 & 75 & 0 & 0 & 1 & 1984 \\
\hline III & X202 & 69 & 0 & 0 & 1.7 & 1985 \\
\hline III & X419 & 96 & 0 & 0 & 1 & 1988 \\
\hline III & X506 & 100 & 2 & 0 & 1 & $<1988$ \\
\hline III & X661 & 73 & 0 & 0 & 0.17 & 1988 \\
\hline III & X699 & 89 & 0 & 0 & 2 & 1988 \\
\hline III & X700 & 85 & 4 & 0 & 2 & 1988 \\
\hline III & X773 & 88 & 0 & 0 & 2 & 1988 \\
\hline III & X852 & 76 & 0 & 0 & 2 & 1989 \\
\hline III & X870 & 63 & 0 & 0 & 0.17 & 1989 \\
\hline III & X874 & 56 & 0 & 0 & 0 & 1989 \\
\hline III & X879 & 71 & 0 & 0 & 2 & 1989 \\
\hline III & X1302 & 91 & 0 & 0 & 2 & 1991 \\
\hline III & X1505 & 100 & 3 & 0 & 1.7 & 1993 \\
\hline III & X1720 & 83 & 2 & 0 & 2 & 2000 \\
\hline III & X1721 & 67 & 0 & 0 & 2 & 2000 \\
\hline III & X1730 & 49 & 11 & 0 & 2 & 2001 \\
\hline III & X1763 & 100 & 1 & 0 & 2 & 2002 \\
\hline III & X1901 & 75 & 0 & 0 & 2 & 2011 \\
\hline III & X1903 & 0 & 0 & 0 & 1.7 & 2011 \\
\hline III & X1904 & 0.33 & 0 & 0 & 1.8 & 2011 \\
\hline \multirow[t]{2}{*}{ III } & LMG8678 & 24 & 0 & 0 & 1.7 & 1987 \\
\hline & $\ldots$ & $\bar{x}=69.5$ & $\bar{x}=1.0$ & $\bar{x}=0$ & $\bar{x}=1.5$ & $\ldots$ \\
\hline pelargonii & LMG7228 & 0 & Wilt & 0 & 0 & 1986 \\
\hline pelargonii & LMG7314 ${ }^{\mathrm{PTf}}$ & 0 & Wilt & 0 & 0.33 & 1986 \\
\hline pelargonii & X1881 & 18 & Wilt & 0 & 0 & 2011 \\
\hline \multirow[t]{2}{*}{ pelargonii } & X1890 & 0 & Wilt & 2 & 0 & 2011 \\
\hline & & $\bar{x}=4.5$ & $\ldots$ & $\bar{x}=0.5$ & $\bar{x}=0.08$ & $\ldots$ \\
\hline begonia & LMG7303 ${ }^{\text {PTg }}$ & 0 & 0 & 0 & 1 & 1989 \\
\hline \multirow[t]{2}{*}{ begoniae } & X1894 & 0 & 0 & 0 & 0.17 & 2011 \\
\hline & & $\bar{x}=0$ & $\bar{x}=0$ & $\bar{x}=0$ & $\bar{x}=0.6$ & $\ldots$ \\
\hline campestris & LMG568 ${ }^{\mathrm{PTh}}$ & 30 & 0 & 0 & 0 & 1957 \\
\hline
\end{tabular}


treat xanthomonad outbreaks as a serious threat to their total production. Infected plants should be removed and destroyed. Other plants within the nursery must be treated as possible pathogen reservoirs. We have shown in this study that high-value crops of poinsettia and geranium can be infected with multiple species of Xanthomonas.
Thus, it would be advised not to cultivate these plants in the same facility. Minor symptoms should never be ignored on these crops because they may represent a pathotype that has the potential of spreading to other hosts or becoming more virulent in a diseaseconducive environment.

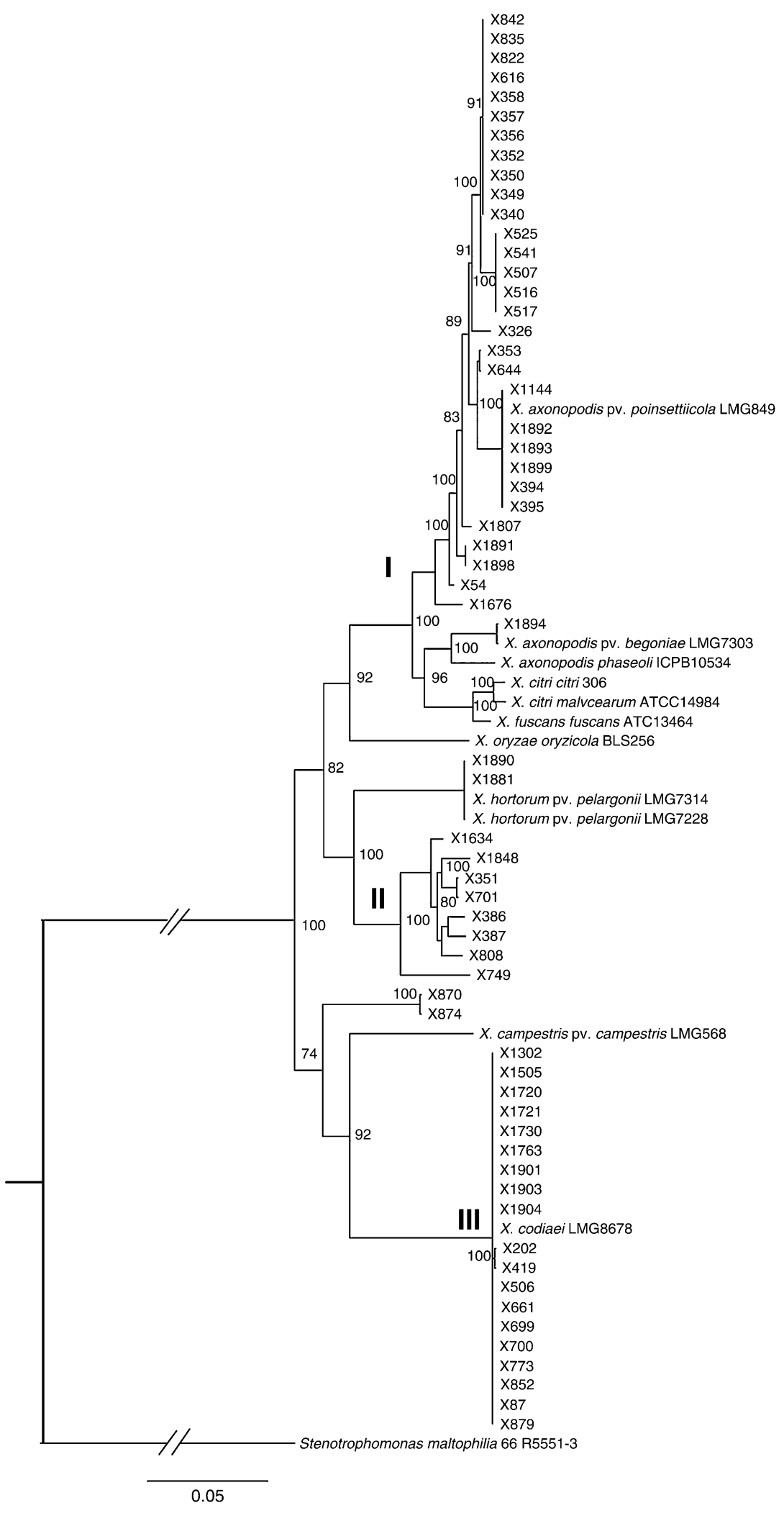

Fig. 1. Bayesian tree and bootstrap values generated from the combined multilocus sequence analysis of six housekeeping genes for Xanthomonas strains associated with poinsettia production. 


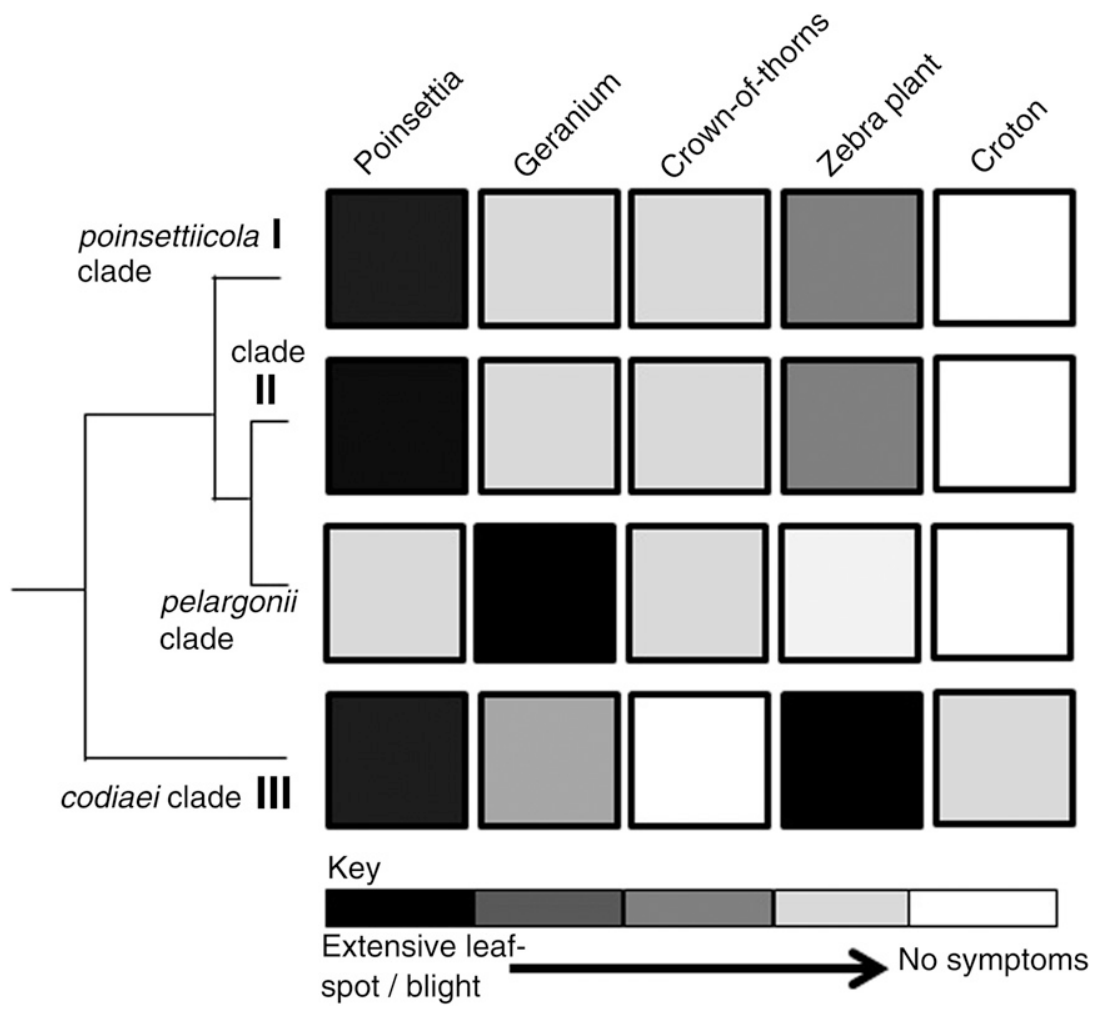

Fig. 2. Virulence of strains from major clades on five different ornamental hosts.

Table 3. Pathogenicity of six representative Xanthomonas strains on geranium under controlled environmental conditions

\begin{tabular}{|c|c|c|c|c|c|}
\hline Species & ID number & Original host & MLSA clade $^{\mathbf{a}}$ & $\begin{array}{c}\text { Average geranium } \\
\text { leaf spots }{ }^{\mathbf{b}}\end{array}$ & $\begin{array}{c}\text { Percent systemic } \\
\text { infection (number) }\end{array}$ \\
\hline Xanthomonas axonopodis pv. poinsetticola & LMG849PTc & Poinsettia & I & 0 & 0 \\
\hline$X$. sp. & X808 & Poinsettia & II & 0 & 0 \\
\hline X. codiaei & LMG8678 & Croton & III & $5.7^{\mathrm{e}}$ & $13(4 / 30)$ \\
\hline$X$. sp. & $\mathrm{X} 1730$ & Geranium & III & $2.23^{\mathrm{e}}$ & $10(3 / 30)$ \\
\hline$X$. hortorum pv. pelargonii & LMG7314 ${ }^{\text {PTf }}$ & Geranium & $\ldots$ & 230 & $100(30 / 30)$ \\
\hline X. campestris pv. campestris & LMG568 ${ }^{\mathrm{PTg}}$ & Cabbage & $\ldots$ & 0 & 0 \\
\hline
\end{tabular}

a MLSA = multilocus sequence analysis.

b Average leaf spots per plant.

c Pathotype strain for X. axonopodis pv. poinsettiicola.

d Type stain $X$. codiae .

e Leaf spots developed on leaf margins and merged; thus, there is a probable underestimation.

${ }^{\mathrm{f}}$ Pathotype strain for $X$. hortorum pv. pelargonii.

g Pathotype strain $X$. campestris pv. campestris.

\section{Acknowledgments}

This research was funded by the Fred C. Gloeckner Foundation and the University of Florida Institute of Food and Agricultural Sciences.

\section{Literature Cited}

Almeida, N. F., Yan, S., Cai, R., Clarke, C. R., Morris, C. E., Schaad, N. W., Schuenzel, E. L., Lacy, G. H., Sun, X., Jones, J. B., Castillo, J. A., Bull, C. T., Leman, S., Guttman, D. S., Setubal, J. C., and Vinatzer, B. A. 2010. PAMDB, a multilocus sequence typing and analysis database and website for plant-associated microbes. Phytopathology 100:208-215.

Benson, D. M., Hall, J. L., Moorman, G. W., Daughtrey, M. L., Chase, A. R., and Lamour, K. H. 2002. The history and diseases of poinsettia, the Christmas flower. Plant Health Prog. Online publication. 10.1094/PHP-2002-0212-01-RV.

Brenner, D. J. 1973. Deoxyribonucleic acid reassociation in the taxonomy of enteric bacteria. Int. J. Syst. Bacteriol. 23, 4:298-307.

Bui Thi Ngoc, L., Verniere, C., Jouen, E., Ah-You, N., Lefeuvre, P., Chiroleu, F., Gagnevin, L., and Pruvost, O. 2010. Amplified fragment length polymorphism and multilocus sequence analysis-based genotypic relatedness among pathogenic variants of Xanthomonas citri pv. citri and Xanthomonas campestris pv. bilvae. Int. J. Syst. Evol. Microbiol. 60:515-525.

Chase, A. R. 1985. Bacterial leaf spot of Codiaeum variegatum cultivars caused by Xanthomonas campestris pv. poinsettiicola. Plant Pathol. 34:446-448.
Hildebrand, D. C., Palleroni, N. J., and Schroth, M. N. 1990. Deoxyribonucleic acid relatedness of 24 xanthomonad strains representing 23 Xanthomonas campestris pathovars and Xanthomonas fragariae. J. Appl. Bacteriol. 68: 263-269.

Hong, J. C., Norman, D. J., Reed, D. L., Momol, M. T., and Jones, J. B. 2012 Diversity among Ralstonia solanacearum strains isolated from the southeastern United States. Phytopathology 102:924-936.

Huelsenbeck, J. P., Ronquist, F., Nielsen, R., and Bollback, J. P. 2001. Bayesian inference of phylogeny and its impact on evolutionary biology. Science 294 2310-2314.

Janssen, P., Coopman, R., Huys, G., Swings, J., Bleeker, M., Vos, P., Zabeau, M., and Kersters, K. 1996. Evaluation of the DNA fingerprinting method AFLP as a new tool in bacterial taxonomy. Microbiology 142:1881-1893.

Johnson, J. L. 1994. Similarity analysis of DNAs. Pages 655-682 in: Methods for General and Molecular Bacteriology. P. Gerhardt, R. G. E. Murray, W. A. Wood, and N. R. Krieg, eds. American Society of Microbiology, Washington, DC.

Louws, F. J., Fulbright, D. W., Taylor Stephens, C., and de Bruijn, F. J. 1994. Specific genomic fingerprints of phytopathogenic Xanthomonas and Pseudomonas pathovars and strains generated with repetitive sequences and PCR. Appl. Environ. Microbiol. 60, 7:2286-2295.

Marcelletti, S., Ferrante, P., and Scortichini, M. 2010. Multilocus sequence typing reveals relevant genetic variation and different evolutionary dynamics among strains of Xanthomonas arboricola pv. juglandis. Diversity 2:1205-1222. 
Marmur, J., and Doty, P. 1962. Determination of the base composition of deoxyribonucleic acid from its thermal denaturation temperature. J. Mol. Biol. 5:109-118.

Martens, M., Dawyndt, P., Coopman, R., Gillis, M., De Vos, P., and Willems, A. 2008. Advantages of multilocus sequence analysis for taxonomic studies: A case using 10 housekeeping genes in the genus Ensifer (including former Sinorhizobium). Int. J. Syst. Evol. Microbiol. 58:200-214.

McFadden, L. A., and Mowry, H. R. 1962. Bacterial leaf spot disease of poinsettia in Florida. Plant Dis. Rep. 46:551-554.

Miller, J. W., and Seymour, C. P. 1972. A comparative study of Corynebacterium poinsettiae and Xanthomonas poinsettiaecola on poinsettia and crown-ofthorns. Proc. Fla. State Hortic. Soc. 85:344-347.

Posada, D., and Crandall, K. A. 1998. Modeltest: Testing the model of DNA substitution. Bioinformatics 14:817-818.

Rademaker, J. L., Hoste, B., Louws, F. J., Kersters, K., Swings, J., Vauterin, L., Vauterin, P., and de Bruijn, F. J. 2000. Comparison of AFLP and rep-PCR genomic fingerprinting with DNA-DNA homology studies: Xanthomonas as a model system. Int. J. Syst. Evol. Microbiol. 50:665-677.

Rademaker, J. L. W., Louws, F. J., Schultz, M. H., Rossbach, U., Vauterin, L., Swings, J., and De Bruijn, F. J. 2005. A comprehensive species to strain taxonomic framework for Xanthomonas. Phytopathology 95:1098-1111.

Ronquist, F., and Huelsenbeck, J. P. 2003. MRBAYES 3: Bayesian phylogenetic inference under mixed models. Bioinformatics 19:1572-1574.
Simões, T., Goncalves, E., Rosato, Y., and Mehta, A. 2007. Differentiation of Xanthomonas species by PCR-RFLP of $r p f \mathrm{~B}$ and $a t p \mathrm{D}$ genes. FEMS Microbiol. Lett. 271:33-39.

Tamura, K., Peterson, D., Peterson, N., Stecher, G., Nei, M., and Kumar, S. 2011 MEGA5: Molecular evolutionary genetics analysis using maximum likelihood, evolutionary distance, and maximum parsimony methods. Mol. Biol. Evol. 28, 10:2731-2739.

Thompson, J. D., Higgins, D. G., and Gibson, T. J. 1994. CLUSTAL W: Improving the sensitivity of progressive multiple sequence alignments through sequence weighting, position specific gap penalties and weight matrix choice. Nucleic Acids Res. 22:4673-4680.

United States Department of Agriculture. 2011. Floriculture Crops 2011 Summary. National Agricultural Statistics Service (NASS), Washington, DC.

Vauterin, L., Rademaker, J., and Swings, J. 2000. Synopsis on the taxonomy of the genus Xanthomonas. Phytopathology 90:677-682.

Vauterin, L., and Swings, J. 1997. Are classification and phytopathological diversity compatible in Xanthomonas? J. Ind. Microbiol. Biotechnol. 19:77-82.

Vos, P., Hogers, R., Bleeker, M., Reijans, M., van de Lee, T., Hornes, M., Frijters, A., Pot, J., Peleman, J., and Kuiper, M. 1995. AFLP: A new technique for DNA fingerprinting. Nucleic Acids Res. 23, 21:4407-4414.

Young, J. M., Park, D. C., Shearman, H. M., and Fargier, E. 2008. A multilocus sequence analysis of the genus Xanthomonas. Syst. Appl. Microbiol. 31: 366-377. 